\title{
VITAMIN D RECEPTOR GENE POLYMORPHISM IN RELATION TO PTH IN CHRONIC KIDNEY DISEASE
}

\author{
Shaden M Hanafy ${ }^{1}$, Gamal E Madi ${ }^{2}$, Manal O El Hamshary, ${ }^{3}$ Walid A Beshari ${ }^{2}$, Heba H Mahmoud ${ }^{1}$
}

\author{
${ }^{1}$ Molecular Biology Department, Genetic Engineering and Biotechnology Research Institute (GEBRI), University of \\ Sadat City, Egypt. \\ ${ }^{2}$ Department of Nephrology, Faculty of Medicine, Ain Shams University, Egypt. \\ ${ }^{3}$ Molecular Diagnostics and Therapeutics Department, Genetic Engineering and Biotechnology Research Institute \\ (GEBRI), University of Sadat City, Egypt.
}

\begin{abstract}
Background/Aim: Vitamin D is a fat-soluble steroid hormone that interacts with its nuclear receptor (VDR) to regulate a variety of biological processes, such as bone metabolism, immune response and transcription of several genes involved in chronic kidney disease (CKD). The aim of this work was to investigate the relation between vitamin D receptor genotype and parathyroid hormone (PTH) in predialysis patients and patient on hemodialysis.

Method: We investigated theVDR Taq-I and VDR Bsm-I gene polymorphisms in 46 patients with chronic kidney disease under conservative treatment, 50 patients on hemodialysis and 70 age and sex matched healthy volunteers. This study was performed by restriction fragment length polymorphism (RFLP).

Results: For the Taq-I polymorphism, the T allele is considered as the risk allele. Carrying T allele increases the risk for both chronic kidney disease and renal failure. The risk for CKD increases by 3.3 fold and the risk for renal failure by 8 folds. For the Bsm1 polymorphism, the $A$ allele is considered as the risk allele. Carrying $A$ allele increases the risk for CKD by 3.6 fold and the risk for renal failure by 8 folds.

Conclusion: Bsm1 and Taq1gene polymorphisms of VDR gene were associated with end stage renal disease (ESRD) and with hyperparathyroidism among Egyptian population. Keywords: chronic kidney disease .vitamin D Receptor. Parathyroid hormone.
\end{abstract}

Keywords: Vitamin D receptor (VDR), chronic kidney disease (CKD), parathyroid hormone (PTH).

\section{INTRODUCTION}

Chronic kidney disease (CKD) is a modern day epidemic and has significant morbidity and mortality implications. Mineral and bone disorders are common in CKD and are now collectively referred to as CKD- mineral and bone disorder (MBD). These abnormalities begin to appear even in early stages of CKD and contribute to the pathogenesis of renal osteodystrophy. Alteration in vitamin $D$ metabolism is one of the key features of CKD-MBD that has major clinical and research implications. CKD is also characterized by vitamin $D$ resistance as there is a progressive loss of vitamin D receptor (VDR) in the parathyroid gland (Fukuda et al., 1993). Low levels of active vitamin D lead to impairments in the binding of active vitamin D to VDR as well as in the binding of the vitamin D-VDR complex to the vitamin D response element (Patel et al., 1995).

CKD is characterized by low 25 hydroxy vitaminD (calcidiol), low 1,25 dihydroxy vitamin D (calcitriol) as well as vitamin D resistance (Nigwekar et al.,
2012). Alterations related to vitamin D metabolism, hyperphosphatemia and hypocalcemia lead to increased synthesis and/or secretion of PTH leading to secondary hyperparathyroidism (Gutierrez et al., 2010).

At least 22 unique loss-of-function mutations have been reported in the VDR gene, which shows several common polymorphisms like Bsml and Taql variations. The $B s m l$ restriction site polymorphism occurs in the intron separating exons VIII and IX. A $\mathrm{T} / \mathrm{C}$ nucleotide substitution (ATT to ATC) leading to a synonymous change at codon 352 (isoleucine) in exon IX has been detected using the restriction enzyme Taql.( Zmuda et al., 2000).

Our hypothesis is that Genetic heterogeneity of several factors seems to play a role in the response of parathyroid function among patients with endstage renal disease. In support of this hypothesis polymorphisms in vitamin $\mathrm{D}$ receptor gene are associated with end-stage renal disease. Thus, the aim of the present work was to investigate the VDR gene polymorphism frequencies and its possible 
influences on biochemical and clinical presentations among Egyptian end-stage renal disease patients undergoing hemodialysis and predialysis patients compared to healthy volunteers.

\section{MATERIALS AND METHODS}

Study population

One hundred and sixty six unrelated Egyptian participants were selected from the dialysis unit and outpatient clinic of Ain Shams Specialized HospitalCairo, Egypt. Participants were divided into 3 groups:

group A : 46 patients under conservative treatment (considered as predialysis group).

group B : 50 patients undergoing hemodialysis sessions.

group C : 70 healty volunteers with matched age \& sex

Patient Exclusion criteria: Chronic usage of antiinflammatory drugs; HIV Infection, immunosuppressive chemotherapy and all types of cancer.

All participants were enrolled in the study after a written informed consent according to the protocol approved by the Ethics Committee of Ain Shams Specialized Hospital.

Levels of serum calcium (Ca), phosphorus (P), alkaline phosphatase (Alk Phos), parathyroid hormone (PTH), urea and creatinine were measured for all participants.

Genotyping of vitamin D receptor (VDR):

Two $\mathrm{ml}$ whole blood were collected in sodium citrate sterile tubes. Genomic DNA was isolated from $300 \mu \mathrm{L}$ of whole venous EDTA-blood using QIAamp DNA Mini kit (QIAGEN, HILDE, GERMANY). DNA samples were stored at $-20 \mathrm{C}$ till genotype analysis.

Taq1 and BsmI VDR polymorphism was carried out by PCR-based Restriction Fragment Length Polymorphism (PCR-RFLP).

VDR Taq1 Genotyping:

PCR amplification of exon 9 of the VDR gene was performed using forward primer: $F 5^{\circ}-C A G$ AGC ATG GAC AGG GAG CAA G-3` and reverse primer: $\mathrm{R}$-5`GGA TGT ACGTCT GCA GTG TG-3`. All reactions were carried out in QB-96 HVD life sciences thermal cycler. PCR cycling conditions consisted of $95^{\circ} \mathrm{C}$ for $5 \mathrm{~min}$ and 35 cycles of denaturing at $94^{\circ} \mathrm{C}$ for $30 \mathrm{~s}$, annealing at $56^{\circ} \mathrm{C}$ for $45 \mathrm{~s}$, and extension at $72^{\circ} \mathrm{C}$ for $50 \mathrm{~s}$ and final extension at $72^{\circ} \mathrm{C}$ for $5 \mathrm{~min}$. The PCR product (344 bp) was digested with Taq1 then the products were electrophoresed against 50 bp DNA step ladder (Fermentas, USA) using $2.5 \%$ agarose gel in 0.5X Tris-acetate-EDTA (TAE). pCR products before and after digestion were visualized under UV after staining with ethidium bromide $(5 \mathrm{mg} / \mathrm{mL})$.
The RFLP is formed by a single-base transition (T/C) at codon 352 in exon 9 of the VDR gene that creates a Taql restriction site. The alleles which result from the cleavage of Taql are designated " $\mathrm{C}$ " (Taql site present, with 2 fragments: 293 and $47 \mathrm{bp}$ ) or " $\mathrm{T}$ " (Taql site absent, with a fragment: $340 \mathrm{bp}$ ).

\section{VDR Bsm1 polymorphism:}

PCR amplification of exon 8 of the VDR gene was performed using forward primer: $F 5^{\circ}$-CAA CCA AGA CTA CAA GTA CCG CGTCAG TGA $-3^{`}$ and reverse primer: R $5{ }^{`}-A A C$ CAG CGG GAA GAG GTC AAG GG 3'. Amplified PCR products were digested using Bsml restriction enzyme. The final volume for $P C R$ reaction $12.5 \mu \mathrm{L}$; the PCR mixture consist of Master Mix (2X) $6.25 \mu$ l (Fermentas, USA), $1.0 \mu \mathrm{l}$ I of forward primer, $1.0 \mu \mathrm{l}$ of reverse primer and 2.5 $\mu \mathrm{l}$ of DNA, $2.75 \mu \mathrm{l}$ distilled water. PCR cycling conditions consisted of $95^{\circ} \mathrm{C}$ for $4 \mathrm{~min}$ and 32 cycles of denaturing at $94^{\circ} \mathrm{C}$ for $30 \mathrm{~s}$, annealing at $56^{\circ} \mathrm{C}$ for $30 \mathrm{~s}$, and extension at $72^{\circ} \mathrm{C}$ for $50 \mathrm{~s}$ and final extension at $72^{\circ} \mathrm{C}$ for $5 \mathrm{~min}$. The PCR products were visualized by $1.8 \%$ agarose gel electrophoresis in 0.5X Tris-Acetate EDTA (TAE) buffer with ethidium bromide staining. The relative size of PCR products were determined by comparison of migration of a 100 bp DNA molecular weight ladder (Fermentas, USA). The RFLP is formed by a single-base transition $(G / A)$ in intron 8 of the VDR gene that creates a Bsml restriction site. The alleles which result from the cleavage of Bsml are designated " $A$ " (Bsml site present, with 2 fragments: 646 and $177 \mathrm{bp}$ ) or " $\mathrm{G}$ " (Bsml site absent, with a fragment of $823 \mathrm{bp}$ ).

Digestion of the amplified products for the two restriction enzymes were as follows: $3.3 \mu \mathrm{l} \mathrm{PCR}$ product, $1 \mu \mathrm{l}$ distilled water, $0.3 \mu \mathrm{l} \mathrm{Bsm1/Taq1}$ enzyme, $0.7 \mu \mathrm{l}$ buffer and incubation at $37^{\circ} \mathrm{C}$ for 3 $\min$.

\section{STATISTICAL ANALYSIS OF RESULTS}

Data were analyzed using IBM SPSS software package version 20.0. Comparison between different groups regarding categorical variables was tested using Chi-square test.

\section{RESULTS}

This study was conducted on 166 unrelated Egyptian individuals. Forty six pre-dialysis patients were $54.3 \%$ male \& $45.7 \%$ female with mean age $55.43 \pm 7.54$. Fifty hemodialysis patients were $78 \%$ male $\& 22 \%$ female with mean age $54.06 \pm 5.17$. Seventy healthy volunteers were $77.1 \%$ male \& $22.9 \%$ female with mean age 52.86 \pm 5.23. The results of comparisons of the biochemical 
parameters between the three studied groups are presented in tables (1 \& 2).

There were highly significant differences in urea, creatinin, alkaline phosphatase, and parathyroid hormone in group A and group B $(p=0.002,0.001$, 0.001 and 0.001 respectively). There was also a significant difference in phosphorous level between group $A$ and group $B(p=0.03)$. No significant difference was observed between the two groups in calcium level $(p=0.291)$.
Genotyping of Vitamin D Receptor Bsml and Tagl polymorphisms:

Frequencies of VDR (Taq1) genotypes and alleles as shown in table 3 revealed that there was a highly significant differences in the distribution of the three genotypes in between the three groups. The TT genotype was the highest in group B (52\%), the CT genotype was the highest in group $A(67.4 \%)$ and CC genotype was highest in the control group (58.6\%).

Table 1: Biochemical data of the studied groups.

\begin{tabular}{|c|c|c|c|c|c|}
\hline & $\begin{array}{c}\text { Group A } \\
(n=46)\end{array}$ & $\begin{array}{l}\text { Group B } \\
(n=50)\end{array}$ & $\begin{array}{l}\text { Control } \\
(n=70)\end{array}$ & ${ }^{\mathrm{kw}} \chi^{2}$ & $\mathbf{p}$ \\
\hline PTH & & & & & \\
\hline Min. - Max. & $4.0-668.0$ & $9.0-2073.0$ & $9.0-60.0$ & & \\
\hline Mean \pm SD. & $231.70 \pm 169.56$ & $552.36 \pm 510.31$ & $28.86 \pm 10.55$ & $106.055^{*}$ & $<0.001^{*}$ \\
\hline Median & 201.50 & 380.50 & 25.50 & & \\
\hline Sig. bet. Grps. & \multicolumn{3}{|c|}{ 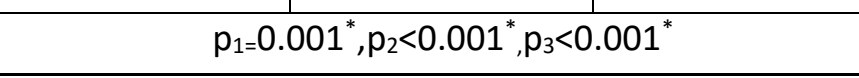 } & & \\
\hline Urea & & & & & \\
\hline Min. - Max. & $2.0-130.0$ & $35.0-108.0$ & $7.0-34.0$ & & \\
\hline Mean \pm SD & $49.85 \pm 29.81$ & $61.98 \pm 15.24$ & $17.39 \pm 6.66$ & $106.080^{*}$ & $<0.001^{*}$ \\
\hline Median & 42.0 & 60.50 & 16.0 & & \\
\hline Sig. bet. Grps. & \multicolumn{3}{|c|}{$\mathrm{p}_{1}=0.002^{*}, \mathrm{p}_{2}<0.001^{*}, \mathrm{p}_{3}<0.001^{*}$} & & \\
\hline Creatinin & & & & & \\
\hline Min. - Max. & $1.40-4.70$ & $4.80-15.50$ & $0.30-1.20$ & & \\
\hline Mean \pm SD. & $2.79 \pm 1.06$ & $9.85 \pm 2.58$ & $0.66 \pm 1.30$ & $144.964 *$ & $<0.001^{*}$ \\
\hline Median & 2.65 & 9.90 & 10.0 & & \\
\hline Sig. bet. Grps. & \multicolumn{3}{|c|}{$p_{1}<0.001^{*}, p_{2}<0.001^{*}, p_{3}<0.001^{*}$} & & \\
\hline
\end{tabular}

KW: Kruskal Wallis test.

Significance between groups using Mann Whitney test

$p_{1}$ : $p$ value for comparing between group $A$ and group $B$

$p_{2}: p$ value for comparing between group $A$ and control group

$p_{3}: p$ value for comparing between group $B$ and Control group

*: Statistically significant at $p \leq 0.05$ 
Table 2: Comparison between the three groups according to calcium, $\mathrm{pH}$ and alkaline phosphatase

\begin{tabular}{|c|c|c|c|c|c|}
\hline & $\begin{array}{l}\text { Group A } \\
(n=46)\end{array}$ & $\begin{array}{l}\text { Group B } \\
(n=50)\end{array}$ & $\begin{array}{l}\text { Control } \\
(n=70)\end{array}$ & $\begin{array}{l}\text { Test of } \\
\text { sig. }\end{array}$ & p \\
\hline $\mathrm{Ca}$ & & & & & \\
\hline Min. - Max. & $5.80-11.60$ & $6.70-11.0$ & $7.0-13.0$ & & \\
\hline $\begin{array}{c}\text { Mean } \pm \text { SD } \\
\text { Median }\end{array}$ & $\begin{array}{c}8.91 \pm 1.23 \\
9.0\end{array}$ & $\begin{array}{c}8.65 \pm 0.96 \\
8.50\end{array}$ & $\begin{array}{c}9.96 \pm 1.30 \\
10.0\end{array}$ & $20.839^{*}$ & $<0.001^{*}$ \\
\hline Sig. bet. Grps. & \multicolumn{3}{|c|}{$\mathrm{p}_{1}=0.291, \mathrm{p}_{2}<0.001^{*} \mathrm{p}_{3}<0.001^{*}$} & & \\
\hline pH & & & & & \multirow[b]{3}{*}{$<0.001^{*}$} \\
\hline Min. - Max. & $1.50-11.0$ & $2.10-8.50$ & $2.50-8.0$ & & \\
\hline $\begin{array}{c}\text { Mean } \pm \text { SD } \\
\text { Median }\end{array}$ & $\begin{array}{c}4.33 \pm 1.72 \\
3.85\end{array}$ & $\begin{array}{c}4.79 \pm 1.42 \\
5.25\end{array}$ & $\begin{array}{c}4.43 \pm 1.08 \\
4.50\end{array}$ & 106.055 & \\
\hline Sig. bet. Grps. & \multicolumn{3}{|c|}{$p_{1}=0.035^{*}, p_{2}=0.0106, p_{3}=0.102$} & & \\
\hline $\begin{array}{l}\text { Alk. Ph. } \\
\text { Min. - Max. }\end{array}$ & $40.0-288.0$ & $23.0-623.0$ & $23.0-156.0$ & & \multirow[b]{2}{*}{$<0.001^{*}$} \\
\hline $\begin{array}{c}\text { Mean } \pm \text { SD } \\
\text { Median }\end{array}$ & $\begin{array}{c}88.72 \pm 50.22 \\
85.50\end{array}$ & $\begin{array}{c}145.28 \pm 105.81 \\
104.0\end{array}$ & $\begin{array}{c}82.60 \pm 34.89 \\
86.0\end{array}$ & $\begin{array}{c}\chi^{2}= \\
16562^{*}\end{array}$ & \\
\hline Sig. bet. Grps. & \multicolumn{3}{|c|}{$p_{1}=0.001^{*}, p_{2}=0.806, p_{3}<0.001^{*}$} & & \\
\hline
\end{tabular}

KW: Kruskal Wallis test, Sig. bet. Grps. using Mann Whitney test

F: F test (ANOVA), Sig. bet. Grps. Using post Hoc test (LSD)

$p_{1}: p$ value for comparing between group $A$ and group $B$

$p_{2}: p$ value for comparing between group $A$ and group Control; $p_{2}$ : $p$ value for comparing between group $B$ and group Control

Table 3: Genotypic \& allelic frequencies of VDR as regard toTaq1 polymorphism among the three studied groups.

\begin{tabular}{|c|c|c|c|c|c|c|c|c|c|c|c|c|}
\hline & \multirow{2}{*}{\multicolumn{2}{|c|}{$\begin{array}{l}\text { Group A } \\
(n=46)\end{array}$}} & \multirow{2}{*}{\multicolumn{2}{|c|}{$\begin{array}{c}\text { Group B } \\
(\mathrm{n}=50)\end{array}$}} & \multirow{2}{*}{\multicolumn{2}{|c|}{$\begin{array}{l}\text { Control } \\
(n=70)\end{array}$}} & \multicolumn{3}{|c|}{ Result of group A vs control } & \multicolumn{3}{|c|}{ Result of group B vs control } \\
\hline & & & & & & & \multirow{2}{*}{ p } & \multirow{2}{*}{ OR } & \multirow{2}{*}{$95 \% \mathrm{Cl}$} & \multirow{2}{*}{ p } & \multirow{2}{*}{ OR } & \multirow{2}{*}{$95 \% \mathrm{Cl}$} \\
\hline & No. & $\%$ & No. & $\%$ & No. & $\%$ & & & & & & \\
\hline \multicolumn{13}{|l|}{ Taq1 } \\
\hline $\mathrm{CC}$ & 8 & 17.4 & 6 & 12.0 & 41 & 58.6 & $<0.001^{\circ}$ & $0.149^{\circ}$ & $0.061-0.366$ & $<0.001^{\circ}$ & $0.096^{*}$ & $0.036-0.256$ \\
\hline CT & 31 & 67.4 & 18 & 36.0 & 27 & 38.6 & $0.002^{*}$ & $3.291^{\circ}$ & $1.506-7.195$ & 0.774 & 0.896 & $0.422-1.900$ \\
\hline TT & 7 & 15.2 & 26 & 52.0 & 2 & 2.9 & $0.015^{*}$ & $6.103^{\circ}$ & $1.208-3.279$ & $<0.001^{\circ}$ & $36.833^{*}$ & $8.124-167.0$ \\
\hline \multicolumn{13}{|l|}{ Allele } \\
\hline $\mathrm{C}$ & 47 & 51.1 & 30 & 30.0 & 109 & 77.9 & $<0.001^{\circ}$ & $0.297^{*}$ & $0.168-0.526$ & $<0.001^{\circ}$ & $0.122^{*}$ & $0.068-0.219$ \\
\hline $\mathrm{T}$ & 45 & 49.9 & 70 & 70.0 & 31 & 22.1 & & $3.367^{*}$ & $1.902-5.960$ & & $8.204^{*}$ & $4.571-14.72$ \\
\hline
\end{tabular}

$\gamma^{2}$ : Chi square test

*: Statistically significant at $p \leq 0.05$

Regarding VDR Bsm1 polymorphism as shown in table 4 there was highly significant differences among the three groups concerning the three genotypes. AG genotype represented (47.8\%) in predialysis patients and AA genotype represented (50\%) in hemodialysis patients, GG genotype particularly appears to be the predominant genotype in the control group (62.9\%). The statistical analysis of the data revealed that carrying AG heterozygote comprises 1.5 fold increased risk for CKD carrying AA homozygote appears in patients on hemodialysis with $50 \%$ and in patient in prehemodialysis with $21.7 \%$. With regard to allelic variance, the A allele is considered as a risk allele (carrying A allele increases the risk for CKD by 3.6 fold and the risk for hemodialysis by 8 folds). 
Table 4: Genotypic \& allelic frequencies of VDR as regard to Bsm1 polymorphism among the three studied groups

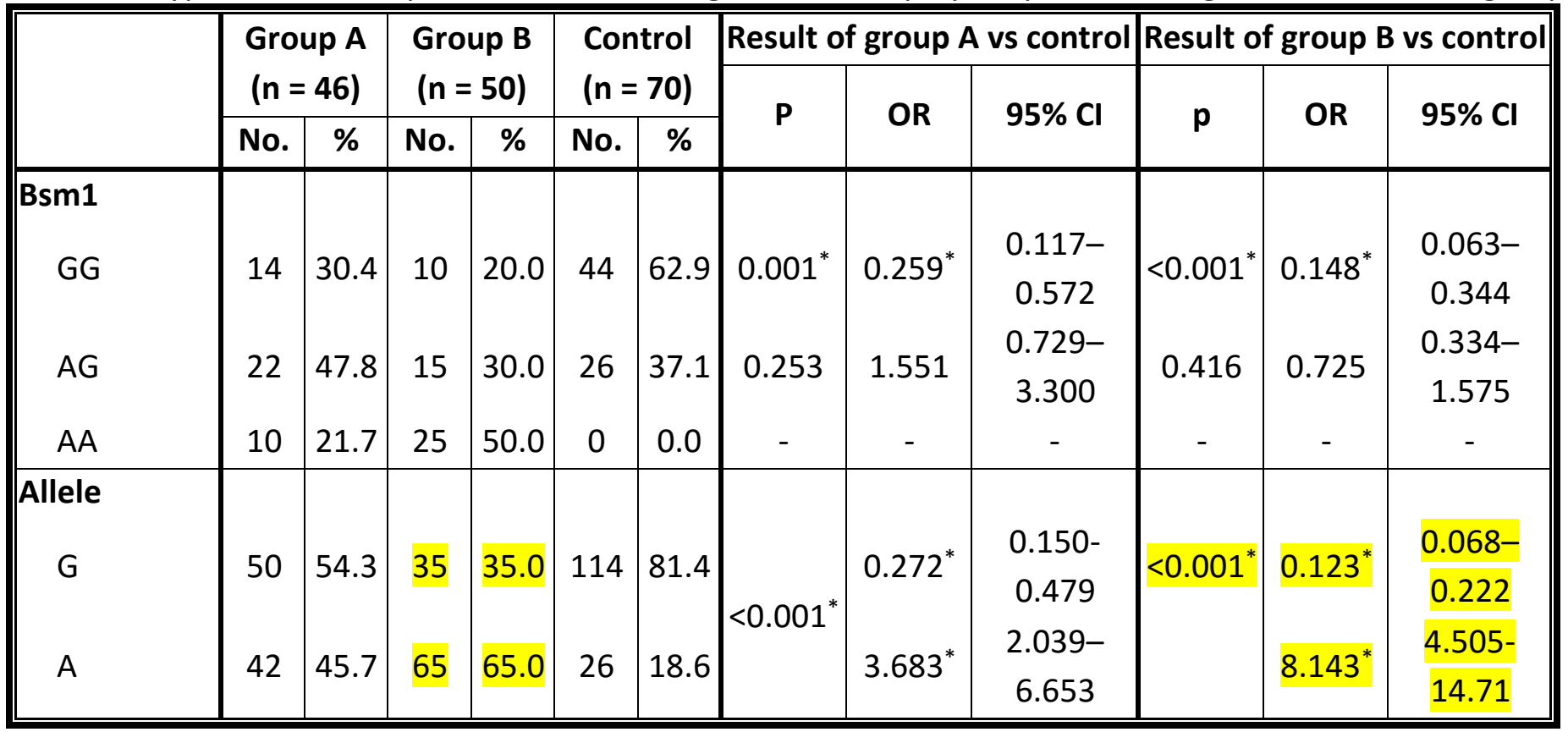

$\chi^{2}$ : Chi square test

*: Statistically significant at $\mathrm{p} \leq 0.05$

Relation between Taq1 and Bsm1 polymorphism with PTH:

There was a highly significant difference in PTH levels with TT genotype of VDR (Taq1) $(p=0.038)$. Also there was a highly significant difference in PTH levels among the three groups for the AA genotype of VDR (Bsm1) $(p<0.001)$ as shown in table 5.

Table (5): Relation between VDR genotypes of Taq1 and Bsm1 with PTH

\begin{tabular}{||c|c|c|c|c||}
\hline PTH & $\begin{array}{c}\text { Group A } \\
(\mathbf{n}=\mathbf{8})\end{array}$ & $\begin{array}{c}\text { Group B } \\
(\mathbf{n}=\mathbf{3 1})\end{array}$ & $\begin{array}{c}\text { Control } \\
(\mathbf{n}=\mathbf{7})\end{array}$ & $\mathbf{p}_{\mathbf{1}}$ \\
\hline Taq1 & & & & \\
CC & $221.8 \pm 59.49$ & $801.33 \pm 360.96$ & $26.98 \pm 1.68$ & 0.245 \\
CT & $243.1 \pm 33.27$ & $451.332 \pm 97.68$ & $31.0 \pm 1.90$ & 0.135 \\
TT & $192.4 \pm 34.68$ & $564.85 \pm 90.91$ & $38.50 \pm 4.50$ & $0.038^{*}$ \\
\hline \multicolumn{1}{|c|}{} & 0.892 & 0.786 & $0.035^{*}$ & \\
\hline Bsm1 & $241.86 \pm 47.21$ & $259.20 \pm 101.30$ & $27.32 \pm 1.53$ & 0.860 \\
GG & $245.55 \pm 34.86$ & $308.47 \pm 61.27$ & $31.46 \pm 2.13$ & 0.599 \\
GA & $187.0 \pm 57.82$ & $815.96 \pm 112.25$ & - & $<0.001^{*}$ \\
AA & 0.556 & $<0.001^{*}$ & $0.057^{\#}$ & \\
\hline \multicolumn{1}{|c|}{$\mathbf{p}$} & & & \\
\hline
\end{tabular}

Data was represented as Mean \pm SEM.

$p: p$ value for Kruskal Wallis test for comparing between the different genotypes

\#p: $p$ value for Mann Whitney test for comparing between GG and GA

$\mathrm{p}_{1}: \mathrm{p}$ value for Mann Whitnev test for comparing between group $\mathrm{A}$ and $\mathrm{B}$

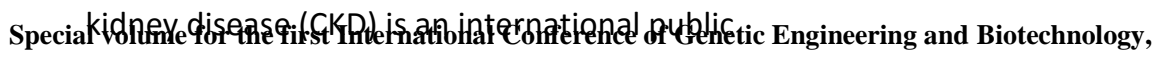


health problem affecting 5-10\% of the world population. It is classified according to severity from stages 1-5. Chronic kidney disease mineral bone disorder (CKD-MBD) is a systemic disorder. The broadened concept of CKD-MBD, includes abnormal mineral metabolism, abnormalities in bone morphology and extra skeletal calcifications. These are closely inter-related and together make major contribution to morbidity, and mortality of patients with CKD (Okoye et al., 2015).

As kidney function declines, there is a progressive deterioration in mineral homeostasis, with a disruption of normal serum and tissue concentrations of phosphorus and calcium, and changes in circulating levels of hormones. These include parathyroid hormone (PTH), 25hydroxyvitamin $\mathrm{D}[25(\mathrm{OH}) \mathrm{D}], 1,2$ dihydroxyvitamin $\mathrm{D}\left[1,25(\mathrm{OH})_{2} \mathrm{D}\right]$, and other vitamin $\mathrm{D}$ metabolites, fibroblast growth factor-23 (FGF-23), and growth hormone. In CKD stage 3, the ability of the kidneys to appropriately excrete phosphate load is diminished, leading to hyperphosphatemia, elevated PTH, and decreased $\left[1,25(\mathrm{OH})_{2} \mathrm{D}\right]$ with associated elevations in the levels of FGF-23. The conversion of $[25(\mathrm{OH}) \mathrm{D}]$ to $\left[1,25(\mathrm{OH})_{2} \mathrm{D}\right]$ is impaired, reducing intestinal calcium absorption and increasing PTH (Abdel-Aziz et al.,2013).

The kidney fails to respond adequately to PTH, which normally promotes phosphaturia and calcium reabsorption, or to FGF-23, which also enhances phosphate excretion. In addition, there is evidence at the tissue level of a downregulation of vitamin $D$ receptor and of resistance to the actions of PTH (Gutierrez et al., 2005).

Vitamin $D$ has an essential role in bone development and mineralization. Vitamin D facilitates these functions by controlling the availability of calcium and phosphate and by regulating the level of hormones such as parathyroid hormone (PTH) (Mohammed, 2011).

Vitamin $D$ receptor is a ligand-activated transcriptional factor that mediates the effects of active vitamin $D$ in a wide variety of tissues and cells, including heart, stomach, pancreas, brain, skin, gonads bone and most cells of the immune system, including $\mathrm{T}$ cells, dendritic cells and macrophages (Machado de Souza et al., 2007). Vitamin D receptor is also present in aortic endothelial and vascular-smooth-muscle cells. In the afferent glomerular arterioles of the kidney, vitamin $D$ is a negative endocrine regulator of rennin (Kobori et al., 2007).

The parathyroid glands secrete parathyroid hormone (PTH), a polypeptide that helps maintain the correct balance of calcium and phosphorous in the body. PTH is involved in the homeostasis of bone metabolism by regulating the level of calcium in the blood, release of calcium from bone, absorption of calcium from the intestine, and excretion of calcium in the urine (Tomasello, 2008).

For patients with Stage 3 or Stage 4 CKD, one of the first abnormalities noted on evaluation may be an isolated increase in $\mathrm{PPTH}$. If the iPTH concentration exceeds the target range, the serum 25(OH)D concentration should be measured, and if that is found to be $<30 \mathrm{ng} / \mathrm{ml}$, ergocalciferol (vitamin $D_{2}$ ) therapy should be initiated. If the concentration of $25(\mathrm{OH}) \mathrm{D}$ is $>30 \mathrm{ng} / \mathrm{ml}$ and the $\mathrm{iPTH}$ concentration exceeds the target range, an activated vitamin D agent should be initiated. Regardless of which vitamin $D$ agent is used, the calcium and phosphorus concentrations must be monitored and maintained within the target range to prevent the precipitation of calcium in soft tissue and vasculature (National Kidney Foundation, 2003).

In this study, there was highly significant differences in urea, creatinine, alkaline phosphatase, and parathyroid hormone between group A and group B ( $p=0.002,0.001,0.001$ and 0.001 respectively). There was also a significant difference in phosphorous level between group $A$ and group $B(p=0.03)$. No significant difference was observed between the two groups in calcium level $(p=0.291)$.

Regarding the association of VDR Taq1 and Bsm1 polymorphisms with PTH levels, there was a highly significant difference in PTH levels in patients with TT and AA genotypes $(p=0.03,0.001$ respectively).

It was observed that patients on hemodialysis showed higher progression of hyperparathyroidism than predialysis patients (Fernandez et al., 1997) reported the influence of Bsm1 vitamin D receptor genotype on the degree of development of secondary hyperparathyroidism in patients with advanced CRF.

This study did not find an influence of this polymorphism on PTH levels in patients at earlier stages of CRF. Perhaps this influence becomes evident only when the parathyroid cell is under the stress generated by CRF and the multiple factors that surround it.

For VDR Bsm1 genotypes it was observed that AA genotype is highly significant $(p<0.001)$ with hyperparathyroidism than other genotypes (GG \&GA where $p=0.86,0.599$ respectively) this is similar to results obtained by (Marco et al., 1999) who reported that the progression of hyperparathyroidism is slower in predialysis patients with GG genotypes than in the other 
genotypes. (Borràs et al., 2003 and Aterini et al., 1996) reported that the $G G$ genotype seems to slow the progression of secondary hyperparathyroidism. For VDR Taq1 genotypes the TT genotype was highly significant $(p<0.001)$ with hyperparathyroidism than other genotypes CC and CT ( $p=0.03,0.2,0.13$ respectively). This is similar to results obtained by (Carling et al., 1997) who suggested an increased frequency of hyperparathyroidism in patients with the TT allele. Also (F.N. Ozdemir 2005) reported that TT variants of the Tagl vitamin D receptor gene influence the development of hyperparathyroidism in hemodialysis patients.

On the other hand, there was an association between genotypes of vitamin $D$ receptor and stages of chronic kidney disease. This study showed that the Bsml polymorphism ( $G$ allele) played a role in protecting patients against end-stage renal disease development. This was maybe due to the fact that patients carrying this allele could have less cardiovascular complications leading to death. The GG genotype seemed to slow the progression of secondary hyperparathyroidism. Also; patients with CKD presented with severe secondary hyperparathyroidism showed lower serum PTH levels with a GG genotype and individuals homozygous for AA presented with higher levels of PTH.

Individuals with AA genotype of BsmI polymorphism $(p=0.001)$ showed higher levels of serum urea, which is a classical serum marker for the presence of CKD. This finding could be an additional indication for $G$ allele having a protective effect against CKD. This study is in agreement with (Machado de Souza et al., 2007) who reported that The Bsml polymorphism allele $\mathrm{G}$ played a role in protecting patients against end-stage renal disease development.

The Taq1 polymorphism allele C played a role in protecting patients against end-stage renal disease development. The CC genotype seemed to slow the progression of secondary hyperparathyroidism. TT genotype presents the highest level of PTH.

\section{Conclusion}

In summary, the association between Taql and Bsml polymorphisms of the VDR gene and ESRD and PTH was investigated. G Allele of Bsml polymorphism was associated with protection against ESRD in Egyptian population.. Callele of Taq1 polymorphism was associated with protection against ESRD in Egyptian population.

Genotype AA of Bsm1 was significantly associated with hyperparathyroidism in hemodialysis patient.
References:

Abdel-Aziz, F. A.; Abdelhameed, A.M.; Reham, M.; Mohamed, A.M.; Wafaa M. and Ramzy, E.R. (2013): Prevalence of Relative Hypoparathyroidism among Hemodialysis Patients: Role of Vitamin D, Aluminium and Magnesium. Journal of Pharmacy and Biological Sciences. 8(5): 41-47.

Aterini, S.; Salvadori, M.; Ippolito, E.; Petrocelli, P.; Pacini, S.; Sineo, L.; Martini, R.; Failli, M.; Amato. M. and Ruggiero, M.(1996): The role of vitamin D receptor gene alleles in the secondary hyperparathyroidism of hemodialysis patients. J Nephrol, 9: 201-6.

Carling, T.; Ridefelt, P. and Hellman P. (1997): Vitamin D receptor polymorphisms correlate to parathyroid cell function in primary hyperparathyroidism. J Clin Endocrinol Metab 82:1772.

F.N. Ozdemir, S.; Sezer, B.; Atac, E.; Tutal, H.; Verdi, F.; Sahin, M. and Haberal.(2005) : Vitamin D Receptor Bsml and Tagl Gene Polymorphisms in a Turkish ESRD Population: Influences on Parathyroid Hormone Response Transplantation Proceedings. $37: 2922-2924$

Fernandez, E.; Fibla, J.; Betriu, A.; Piulats, J.M.; Almirall, J. and Montoliu, J.(1997): Association between vitamin $D$ receptor gene polymorphism and relative hypoparathyroidism in patients with CRF. JAm Soc Nephrol 8:1546-1552.

Fukuda, N.; Tanaka, H.; Tominaga, Y.; Fukagawa, M.; Kurokawa, k. and Seino, Y. (1993) : Decreased 1,25dihydroxyvitamin D3 receptor density is associated with a more severe form of parathyroid hyperplasia in chronic uremic patients. J Clin Invest;92:14361443

Gutierrez, O.M. (2010) : Fibroblast growth factor 23 and disordered vitamin $D$ metabolism in chronic kidney disease: updating the "trade-off" hypothesis. Clin J Am Soc Nephrol;5:1710-1716.

Gutierrez, O.; Isakova, T.; Rhe,e E.(2005): Fibroblast growth factor-23 mitigates hyperphosphatemia but accentuates calcitriol deficiency in chronic kidney disease. J Am Soc Nephrol. 6: 2205-2215 


\begin{abstract}
Machado de Souza C.; Ribeiro Braosi A.P.; $\quad$ Luczyszyn S.M.; Rodrigues Ávila A.; Barbosa de Brito Jr. R.; Aparecido Ignácio S.; Probst C.M. Riella M.C.; Santos Sotomaior V.; Távora Mira M.; Pecoits-Filho R. and Trevilatto P.C.(2007): Association between Vitamin $D$ Receptor Gene Polymorphisms and Susceptibility to Chronic Kidney Disease and Periodontitis. Blood Purif. 25:411-419
\end{abstract}

Marco, M.P.; Martı́nez, I.; Amoedo, M.L.; Borra's, M.; Mercè Borràs, Vicens Torregrossa, Anna Oliveras, Jaume Almirall, M Paz Marco1, Angels Betriu, Marisa Martin1, Salomé Muray, Joan Fibla, Elvira Fernández (2003): BB genotype of the vitamin D receptor gene polymorphism postpones parathyroidectomy in hemodialysis patients J NEPHROL 16: 116-120.

Mohammed, S.R. (2011): Osteo-Renal Regulation of Systemic Phosphate Metabolism IUBMB Life, 63(4): 240-247.

National Kidney Foundation (2003): Bone metabolism and disease in chronic kidney disease. Am J Kidney Dis 43:S1-S201.

Nigwekar, S.U.; Bhan, I. and Thadhani, R. ( 2012) : Ergocalciferol and cholecalciferol in CKD. Am J Kidney Dis;60:139-156. of vitamin D. Am J Clin Nutr., 61, 638S-645S.

Okoye, J.U.; Arodiwe, E.B.; Ulasi, I.I.; Ijoma, C.K.; Onodugo, O.D. (2015): Prevalence of CKD-MBD in pre-dialysis patients using biochemical markers in Enugu, South-East Nigeria. Afri Health Sci. 15(3):941-948.

Patel, S.R.; Ke, H.Q.; Vanholder, R.; Koenig, R.J. and Hsu, C.H. (1995) : Inhibition of calcitriol receptor binding to vitamin $D$ response elements by uremic toxins. J Clin Invest;96:50-59.

Saracho, R.; Almirall, J.; Fibla, J. and Ferna'ndez, E.(1999): Vitamin D receptor genotype influences parathyroid hormone and calcitriol levels in predialysis patients. Kidney Int 56:1349- 1353.

Sarah Tomasello (2008): Secondary

Hyperparathyroidism and Chronic Kidney Disease.

Diabetes Spectrum, 21 (1): 19-25.
Zmuda, J.M.; Cauley, J.A. and Farrel, R.E. (2000):

Molecular epidemiology of vitamin $D$ receptor gene variants. Epidemiol Rev 22:203. 